Elam, J. F., Gee, L. L. \& Couch, J. R. (r95I). Proc. Soc. exp. Biol., N. Y., 78, 832.

Fell, R. V. \& Stephenson, E. L. (1953). Poult. Sci. 32, 1092.

Francis, D. W. \& Schaffner, C. S. (1956). Poult. Sci. 35, 1371.

Gordon, R. S. \& Sizer, I. W. (1955). Science, 122, 1270.

Jacobs, R. L., Elam, J. F., Anderson, G. W., Gee, L. L., Fowler, J. \& Couch, J. R. (1953). F. Nutr. 5r, 507.

Jowsey, J. R., Cook, F. D., Macgregor, H. I. \& Blakely, R. M. (1957). Nature, Lond., 180, 923.

Jukes, T. H. (1956). Fed. Proc. 15, 559.

Libby, D. A. \& Schaible, P. J. (1955). Quart. Bull. Mich. agric. Exp. Sta. 38, 241.

Machlin, J. J. \& Pearson, P. B. (1956). Proc. Soc. exp. Biol., N.Y., 93, 204.

Mellen, W. J. \& Waller, E. F. (1954). Poult. Sci. 33, 1о36.

Taylor, J. H. (1957). Vet. Rec. 69, 278.

Taylor, J. H. \& Gordon, W. S. (1955). Nature, Lond., 176, 3 I 2.

Wacker, A., Heyl, W., Büechl, H. \& Holthoff, H. J. (1955). ArzneimForsch. 5, 702.

Wacker, A., Heyl, W., Büechl, H. \& Holthoff, H. J. (1956). ArzneimForsch. 6, 7r 2.

Wilson, J. E. \& du Vigneaud, V. (1948). Science, ro7, 653.

Wilson, J. E. \& du Vigneaud, V. (1950). F. biol. Chem. 184, 63.

\title{
The metabolism in sheep of the alkaline earth products of fission
}

\section{The absorption and excretion of ${ }^{45} \mathrm{Ca}$ and ${ }^{89} \mathrm{Sr}$ by Blackface wethers}

\author{
By H. G. JONES* AND W. S. MACKIE \\ Rowett Research Institute, Bucksburn, Aberdeen \\ (Received 31 Fanuary 1959-Revised 8 May 1959)
}

Strontium-9o, which is one of the products of nuclear fission, is deposited in the United Kingdom roughly in proportion to the rainfall in any given area. Its uptake by vegetation is maximal in the permanent natural hill pastures where the soil is acid and deficient in many nutrients including calcium and phosphorus. For these reasons hill sheep retain more ${ }^{90} \mathrm{Sr}$ than other animals which are important as sources of food for man (Bryant, Chamberlain, Morgan \& Spicer, 1957). Grazing sheep are therefore very sensitive indicators of the pollution of a given area by radioactive fallout, and it is important that the metabolism of strontium in sheep be studied.

Strontium behaves very similarly to calcium, both chemically and physiologically. However, during the passage of the two elements through the animal body various quantitative differences in their behaviour may be observed. These amount to a 'discrimination' by the animal against strontium and in favour of calcium. The chief sites where this discrimination occurs in the non-lactating animal appear to be the alimentary canal during absorption and the kidney during the excretion of calcium and strontium in the urine (Comar, Russell \& Wasserman, 1957).

Discrimination against strontium during absorption from the alimentary canal has been reported in rats (Comar, Wasserman \& Nold, 1956; Harrison, Jones \& Sutton,

* Seconded from the M.R.C. Radiobiological Research Unit, A.E.R.E., Harwell, Didcot, Berks. 
1957), in man (Harrison, Raymond \& Tretheway, 1955) and in goats (Wasserman, Lengemann \& Comar, I958). On the other hand, Comar \& Wasserman (1956) found no difference between the absorption of ${ }^{45} \mathrm{Ca}$ and ${ }^{89} \mathrm{Sr}$ by yearling steers. Alexander, Nusbaum \& MacDonald (1956) compared the natural calcium:strontium ratios in the diets and skeletons of various species of wild and laboratory animals. The ratio found in the skeletons of most animals was four to five times as high as that in the diet.

During the urinary excretion of calcium and strontium discrimination against strontium of varying magnitudes has been reported in man (Harrison et al. 1955), in rats (Harrison et al. 1957), in cattle (Comar \& Wasserman, 1956) and in goats (Wasserman et al. 1958). Much more calcium and strontium are excreted in the urine of the non-ruminant animal than in that of the ruminant. As the kidney is one of the two main sites wherein discrimination against strontium by the animal occurs, the fact that excretion of calcium and strontium by the ruminant kidney is so small may contribute to the higher ${ }^{90} \mathrm{Sr}$ concentration found in some ruminants during surveys of the extent of contamination of the biosphere by radioactive fallout (Bryant $e t$ al. 1957).

The different behaviour of calcium and strontium in the organism may be studied by several methods. The calcium and strontium content of the diet, tissues and excreta may be estimated, but it requires a fairly elaborate analytical procedure for the estimation of very small quantities of strontium in the presence of large quantities of calcium. Alexander et al. (1956) used a spectrographic method, whereas Harrison et al. (1955, 1957) used the method of neutron activation analysis. With small laboratory animals, the method of lifelong feeding on a diet with a known ratio of radiostrontium to stable calcium may be used (Comar, Whitney \& Lengemann, 1955). However, this method becomes extremely complicated when larger animals such as ruminants are considered. A third method consists in the use of radioactive isotopes of calcium and strontium given simultaneously. The ratio of one nuclide to the other is then estimated in tissues and excreta. This method has been used by Comar \& Wasserman (1956) and Wasserman et al. (1958) and is the most convenient method for use with ruminants.

In the present work ${ }^{45} \mathrm{Ca}$ and ${ }^{89} \mathrm{Sr}$ were given simultaneously to wether sheep confined in metabolism cages and the behaviour of the two nuclides was studied. Strontium-89, which like ${ }^{90} \mathrm{Sr}$ is a component of radioactive fallout, was used instead ${ }^{\circ}{ }^{90} \mathrm{Sr}$ because of its lower toxicity. Its physical half-life (54 days) is much shorter than that of ${ }^{90} \mathrm{Sr}$ (28 years). Secondly, the product of the decay of ${ }^{89} \mathrm{Sr}$ is ${ }^{89} \mathrm{Y}$ which is not radioactive, whereas that of ${ }^{90} \mathrm{Sr}$ is ${ }^{90} \mathrm{Y}$ which is itself radioactive. The assay of ${ }^{89} \mathrm{Sr}$ is therefore simpler than that of ${ }^{90} \mathrm{Sr}$. Chemically, ${ }^{89} \mathrm{Sr}$ and ${ }^{90} \mathrm{Sr}$ are indistinguishable.

\section{EXPERIMENTAL}

Animals and materials. Scottish Blackface wethers aged I2-I5 months and weighing 24-32 kg were kept for at least 3 months on a diet of hay and concentrates. The ration consisted of $32 \mathrm{~g}$ of each $/ \mathrm{kg}$ body-weight/day. The diet provided about $100 \mathrm{mg}$ of calcium $/ \mathrm{kg}$ body-weight/day. All the sheep were in calcium balance. 
The ${ }^{45} \mathrm{Ca}$ was of high specific activity (about I $\mathrm{mc} / \mathrm{mg}$ calcium). The ${ }^{89} \mathrm{Sr}$ was carrierfree material and its ${ }^{90} \mathrm{Sr}$ content was less than I $\%$. Both nuclides were administered as their chlorides and no carrier calcium or strontium was added.

Procedure. After being maintained on weighed amounts of the diet for about 3 months, the sheep were transferred to metabolism cages which permitted separate collection of urine and faeces. The animals were kept in the cages for several days before the experiments were begun so that they became used to their surroundings.

In the first experiment three sheep were injected intravenously with a mixture of the two nuclides and three others were given the same quantities by means of a plastic tube into the rumen. The quantities of radioactivity given to each sheep were $33 \mu \mathrm{c}$ ${ }^{45} \mathrm{Ca}$ and $7 \mu \mathrm{c}{ }^{89} \mathrm{Sr} / \mathrm{kg}$ body-weight. Balances of stable calcium, ${ }^{45} \mathrm{Ca}$ and ${ }^{89} \mathrm{Sr}$ were made for 10 days with the sheep, which were then killed by sodium pentobarbitone given intravenously. Frequent blood samples were taken during the experimental period and the serum was separated and analysed for ${ }^{45} \mathrm{Ca}$, ${ }^{89} \mathrm{Sr}$ and stable calcium. After death a whole femur of each animal was dissected as free as possible from soft tissue and wet-ashed with nitric acid. Surplus nitric acid was boiled off with water and the mixture acidified again with hydrochloric acid. The calcium and strontium present were precipitated with ammonium oxalate and the resulting precipitate was assayed for ${ }^{45} \mathrm{Ca},{ }^{89} \mathrm{Sr}$ and stable calcium. Each day's urine and faeces were dried and ashed in a muffle furnace, the former at $500^{\circ}$ and the latter at $700^{\circ}$. The resulting ash was dissolved in $6 \mathrm{~N}$-hydrochloric acid, the calcium and strontium were precipitated as oxalate and this precipitate was assayed for ${ }^{45} \mathrm{Ca},{ }^{89} \mathrm{Sr}$ and stable calcium.

In the second experiment one sheep was injected intravenously with $50 \mu \mathrm{c}{ }^{45} \mathrm{Ca}$ and $\mathrm{I} 6 \mu \mathrm{c}{ }^{89} \mathrm{Sr} / \mathrm{kg}$ body-weight. It was killed by an intravenous injection of sodium pentobarbitone $\mathrm{I} h \mathrm{~h}$ later and the alimentary canal was ligated in many places (the small intestine into four equal lengths), removed and washed thoroughly. The contents of the various segments were dried, ashed in a muffle furnace at $700^{\circ}$ and the resulting ash was dissolved in $6 \mathrm{~N}$-hydrochloric acid. Subsequent treatment of the solutions was similar to that in the first experiment. A proportion of the mixed rumen contents was taken, but with the other organs the whole contents were used. This experiment was repeated with two more sheep given ${ }^{89} \mathrm{Sr}$ only.

Chemical and physical methods. Calcium was estimated in diet, bones and excreta by the permanganate method (Vogel, 195I). The method used to estimate calcium in serum was that of Clark \& Collip (1925).

The ${ }^{45} \mathrm{Ca}$ and ${ }^{89} \mathrm{Sr}$ were assayed as thin films of their oxalates slurried upon aluminium planchettes. The thickness of the dried films was equivalent to about $0.5 \mathrm{mg} /$ $\mathrm{cm}^{2}$. A Geiger-Müller counter with a thin mica end-window was used. The two radiations were distinguished by means of an aluminium filter of $69 \cdot \mathrm{I} \mathrm{mg} / \mathrm{cm}^{2}$. When ${ }^{89} \mathrm{Sr}$ was used alone it was estimated in solution by means of a Veall-type GeigerMüller counter. 
RESULTS

\section{First experiment}

Calcium balance. Table I gives the results of the calcium balances. The six animals were in calcium balance and most of the excreted calcium was in the faeces. Urinary calcium amounted on the average to little more than $I \%$ of the faecal excretion and in individual sheep the value was often much less.

Table I. Calcium balances on six Blackface wethers

(Figures in parentheses represent standard deviations of individual observations)

\begin{tabular}{|c|c|c|c|c|}
\hline $\begin{array}{c}\text { Sheep } \\
\text { no. }\end{array}$ & $\begin{array}{c}\text { Ca intake/ } \\
\text { day }(\mathrm{g})\end{array}$ & $\begin{array}{l}\text { Mean faecal } \\
\mathrm{Ca} / \text { day }(\mathrm{g})\end{array}$ & $\begin{array}{l}\text { Mean urinary } \\
\mathrm{Ca} / \text { day }(\mathrm{g})\end{array}$ & $\begin{array}{c}\text { Mean serum Ca } \\
(\mathrm{mg} / \mathrm{ro0} \mathrm{ml})\end{array}$ \\
\hline I & $3 \cdot 2$ & $3 \cdot 0( \pm 0 \cdot 2)$ & $0.011( \pm 0.009)$ & $10.4( \pm 0.1)$ \\
\hline 2 & $2 \cdot 8$ & $2.6( \pm 0.9)$ & $0.031( \pm 0.013)$ & $10.4( \pm 0.3)$ \\
\hline 3 & $2 \cdot 8$ & $2.8( \pm 0.3)$ & $0.057( \pm 0.050)$ & $10.6( \pm 0.1)$ \\
\hline 4 & $2 \cdot 8$ & $2.3( \pm 0.6)$ & $0.007( \pm 0.005)$ & $9.7( \pm 0.4)$ \\
\hline 5 & $2 \cdot 8$ & $2 \cdot 3( \pm 0 \cdot 1)$ & $0.034( \pm 0.019)$ & $9.8( \pm 0.2)$ \\
\hline 6 & $2 \cdot 8$ & $2.7( \pm 0.4)$ & $0.045( \pm 0.029)$ & $10.3( \pm 0.3)$ \\
\hline Mean & $2 \cdot 9$ & $2 \cdot 6$ & 0.031 & IO' I \\
\hline
\end{tabular}

Table 2. Retention and excretion of ${ }^{45} \mathrm{Ca}$ and ${ }^{89} \mathrm{Sr}$ Io days after their simultaneous administration orally or intravenously to Blackface wethers, expressed as a percentage of the dose

\begin{tabular}{lccc} 
& & & \multicolumn{1}{c}{ Ratio, } \\
& ${ }^{45} \mathrm{Ca}$ & ${ }^{89} \mathrm{Sr}$ & ${ }^{45} \mathrm{Ca}:{ }^{89} \mathrm{Sr}$ \\
Faeces & Oral administration & \\
Urine & 63.2 & 85.0 & 0.74 \\
Femur & $0.2 \mathrm{I}$ & 0.82 & 0.26 \\
Skeleton (calculated) & $1 \cdot 13$ & 0.27 & $4 \cdot 19$ \\
& 27.4 & 6.6 & - \\
Faeces & Intravenous & injection (three sheep) & \\
Urine & 26.7 & 25.7 & $1 \cdot 04$ \\
Femur & $0.7 \mathrm{I}$ & 4.20 & 0.17 \\
Skeleton (calculated) & 2.67 & 2.29 & $1 \cdot 16$ \\
& 65.1 & 55.8 & -
\end{tabular}

Retention and excretion of the nuclides. The results are shown in Table 2. When the nuclides were given orally, over four times as much ${ }^{45} \mathrm{Ca}$ as ${ }^{89} \mathrm{Sr}$ was deposited in the femur and more ${ }^{89} \mathrm{Sr}$ than ${ }^{45} \mathrm{Ca}$ was excreted in the faeces. Most of the dose of both nuclides was excreted by this route. The urinary excretion of ${ }^{89} \mathrm{Sr}$ was much higher than that of ${ }^{45} \mathrm{Ca}$. When the nuclides were given intravenously, about one-quarter of the dose of each nuclide was excreted in the faeces within Io days of administration. There appeared to be no difference between ${ }^{45} \mathrm{Ca}$ and ${ }^{89} \mathrm{Sr}$ in this respect. Well over half the dose of each nuclide was retained by the skeleton. There was again a marked difference in the urinary excretion of the two nuclides. Thus approximately six times as much ${ }^{89} \mathrm{Sr}$ as ${ }^{45} \mathrm{Ca}$ was so excreted.

Retention of each nuclide by the whole skeleton was calculated on the assumption that the distribution of ${ }^{45} \mathrm{Ca}$ and ${ }^{89} \mathrm{Sr}$ in the femur is similar to that in the whole skeleton. It has been shown recently (Morgan \& Wilkins, 1959) that the distribution of 
${ }^{90} \mathrm{Sr}$ fallout in the skeleton of the sheep is reasonably uniform. The maximum error involved in extrapolating from a single bone to the whole skeleton is only about $10 \%$. A femur from one of these wether sheep was taken to represent $4.1 \%$ of the skeleton by weight (Duckworth \& Hill, I958).

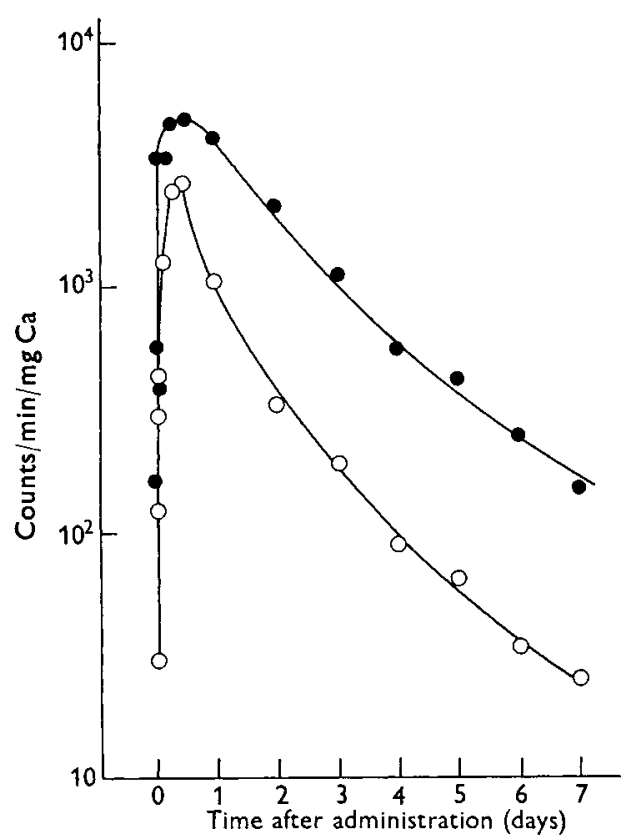

Fig. I

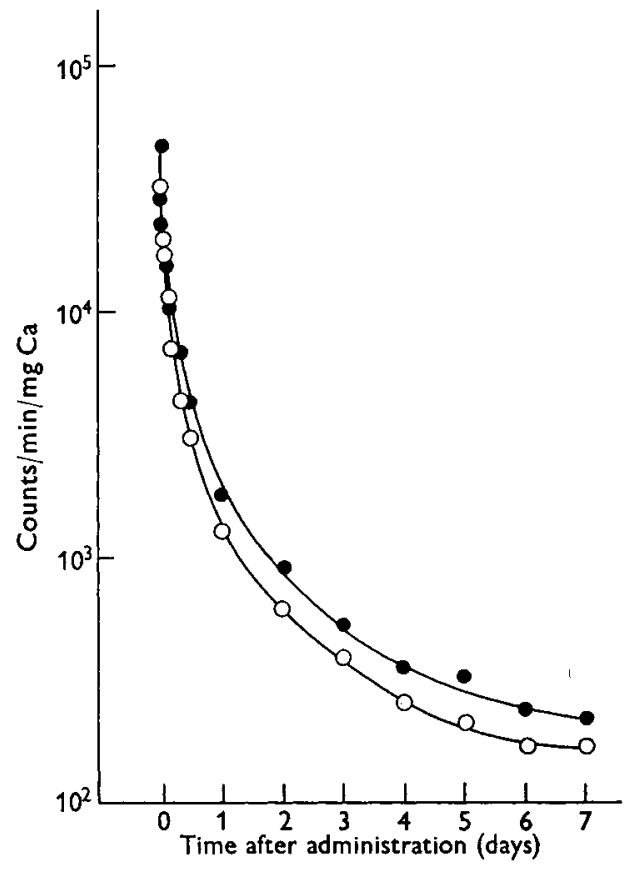

Fig. 2

Fig. I. ${ }^{45} \mathrm{Ca}(-\bullet)$ and ${ }^{89} \mathrm{Sr}\left({ }^{-}-0\right)$ in serum after oral administration: values corrected to a ${ }^{45} \mathrm{Ca}:{ }^{89} \mathrm{Sr}$ ratio of 1.00 in the material administered. Mean values for three sheep.

Fig. $2 .{ }^{45} \mathrm{Ca}(-\bullet)$ and ${ }^{89} \mathrm{Sr}(0-0)$ in serum after intravenous administration: values corrected to a ${ }^{45} \mathrm{Ca}:{ }^{89} \mathrm{Sr}$ ratio of $\mathrm{I} \cdot 00$ in the material administered. Mean values for three sheep.

Figs. I and 2 show the disappearance of ${ }^{45} \mathrm{Ca}$ and ${ }^{89} \mathrm{Sr}$ from serum with time after their oral and intravenous administration. With both methods of administration ${ }^{89} \mathrm{Sr}$ disappeared from serum more quickly than ${ }^{45} \mathrm{Ca}$. However, the shapes of the curves for both nuclides were similar. After oral administration the level of ${ }^{45} \mathrm{Ca}$ in the serum was always considerably higher than that of ${ }^{89} \mathrm{Sr}$.

\section{Second experiment}

In the second experiment the distribution of ${ }^{45} \mathrm{Ca}$ and ${ }^{89} \mathrm{Sr}$ I $\mathrm{h}$ after their simultaneous intravenous injection was studied. The results are set out in Tables 3 and 4 . The appearance of both nuclides in the alimentary canal was quite rapid, some $4-5 \%$ being present in the lumen of the canal within $\mathrm{I} h$. Since the first animal used showed that the distribution of ${ }^{45} \mathrm{Ca}$ and ${ }^{89} \mathrm{Sr}$ within the alimentary canal was similar and since ${ }^{45} \mathrm{Ca}$ is very expensive, the replication was made with ${ }^{89} \mathrm{Sr}$ only. The first experiment had shown that the excretion of ${ }^{45} \mathrm{Ca}$ and ${ }^{89} \mathrm{Sr}$ in the faeces was quantitatively similar. During the period of the experiment some passage of contents through the canal 
would have occurred but it is apparent that most (over $60 \%$ ) of the ${ }^{89} \mathrm{Sr}$ was excreted into the small intestine. However, quite significant quantities of both nuclides were found in other parts of the alimentary canal, in particular the reticulo-rumen and the large intestine.

Table 3. Distribution of ${ }^{45} \mathrm{Ca}$ and ${ }^{89} \mathrm{Sr}$ found in the contents of the alimentary canal I $h$ after their intravenous injection into a Blackface wether

\begin{tabular}{|c|c|c|c|c|}
\hline \multirow{2}{*}{ Organ } & \multicolumn{2}{|c|}{${ }^{45} \mathrm{Ca}$} & \multicolumn{2}{|c|}{${ }^{89} \mathrm{Sr}$} \\
\hline & $\begin{array}{l}\text { As percentage } \\
\text { of administered } \\
\text { dose }\end{array}$ & $\begin{array}{c}\text { As percentage } \\
\text { of that found } \\
\text { in alimentary } \\
\text { canal }\end{array}$ & $\begin{array}{c}\text { As percentage } \\
\text { of administered } \\
\text { dose }\end{array}$ & $\begin{array}{c}\text { As percentage } \\
\text { of that found } \\
\text { in alimentary } \\
\text { canal }\end{array}$ \\
\hline Reticulo-rumen & 0.94 & $15 \cdot 2$ & 0.65 & $14^{*} I$ \\
\hline Omasum & 0.06 & $\mathbf{I} \cdot 0$ & 0.05 & $\mathbf{I} \cdot \mathbf{I}$ \\
\hline Abomasum & 0.17 & $2 \cdot 7$ & 0.16 & $3 \cdot 5$ \\
\hline $\begin{array}{c}\text { Small intestine: } \\
\text { Segment I } \\
\text { Segment } 2 \\
\text { Segment } 3 \\
\text { Segment } 4\end{array}$ & $\begin{array}{l}0.33 \\
0.43 \\
2.29 \\
0.87\end{array}$ & $\begin{array}{r}5 \cdot 3 \\
6 \cdot 9 \\
36 \cdot 9 \\
14 \cdot 0\end{array}$ & $\begin{array}{l}0.23 \\
0.35 \\
I \cdot 74 \\
0.53\end{array}$ & $\begin{array}{r}5 \cdot 0 \\
7 \cdot 6 \\
27 \cdot 8 \\
11 \cdot 5\end{array}$ \\
\hline Caecum & 0.50 & $8 \cdot x$ & 0.46 & $10 \cdot 0$ \\
\hline Large intestine & $0.6 \mathrm{I}$ & $10 \cdot 0$ & 0.43 & $9 \cdot 4$ \\
\hline
\end{tabular}

Table 4. Distribution of ${ }^{89} \mathrm{Sr}$ found in the contents of the alimentary canal I $h$ after its intravenous injection into Blackface wethers

(Mean values for three animals)

$\begin{array}{lcc}\text { Organ } & \begin{array}{c}\text { As percentage } \\ \text { of administered } \\ \text { dose }\end{array} & \begin{array}{c}\text { As percentage } \\ \text { of that found } \\ \text { in alimentary } \\ \text { canal }\end{array} \\ \text { Reticulo-rumen } & 0.59 & 13.6 \\ \text { Omasum } & 0.06 & 1.4 \\ \text { Abomasum } & 0.13 & 3.0 \\ \text { Small intestine: } & & \\ \text { Segment I } & 0.21 & 4.8 \\ \text { Segment 2 } & 0.52 & 12.0 \\ \text { Segment 3 } & 1.26 & 29.0 \\ \text { Segment 4 } & 0.83 & 18.9 \\ \text { Caecum } & 0.38 & 8.7 \\ \text { Large intestine } & 0.36 & 8.3\end{array}$

It was considered that some quantity of the radioactivity might possibly be excreted through the sebaceous glands. Consequently, when one of the sheep concerned in the second experiment was killed, an area of its flank consisting of about 6 in. square was shaved and the wool assayed for radioactivity. None was found. 


\section{DISCUSSION}

The main site of the discrimination between orally administered calcium and strontium in wether sheep appears to be the alimentary canal during absorption. Thus when ${ }^{45} \mathrm{Ca}$ and ${ }^{89} \mathrm{Sr}$ were given to these animals orally four times as much ${ }^{45} \mathrm{Ca}$ as ${ }^{89} \mathrm{Sr}$ was detectable in the femur. The levels of ${ }^{45} \mathrm{Ca}$ in the serum were also consistently higher than those of ${ }^{89} \mathrm{Sr}$, by a factor of nearly three. This fact seems to indicate quite marked discrimination during the absorption process. The slight difference between the ${ }^{45} \mathrm{Ca}:{ }^{89} \mathrm{Sr}$ ratios in femur and serum obtained in this experiment would seem to indicate some small discrimination in the process of exchange of calcium and strontium between the two tissues. This observation was not supported by the results obtained when the nuclides were injected intravenously, when almost exactly equal quantities of the two were found in the femur.

Discrimination also occurred during the excretion of the nuclides in the urine. Thus after their intravenous injection, six times as much ${ }^{89} \mathrm{Sr}$ as ${ }^{45} \mathrm{Ca}$ was excreted in the urine. This discrimination is much higher than that found in non-ruminants (Harrison et al. 1955, 1957) and somewhat higher than that found in goats (Wasserman et al. 1958). However, this particular discrimination does not materially affect the figures for the retention of ${ }^{45} \mathrm{Ca}$ and ${ }^{89} \mathrm{Sr}$ because, quantitatively, the urinary excretion of calcium is so small. Thus after its intravenous injection twenty-eight times as much ${ }^{45} \mathrm{Ca}$ was excreted into the alimentary canal as through the kidney. There appeared to be no discrimination between calcium and strontium during excretion into the alimentary canal and there was no difference in the initial rate of appearance of the two in the various regions of the alimentary canal.

The rates of appearance of ${ }^{89} \mathrm{Sr}$ in the various parts of the gut were similar to those found in the rat (Jones \& Coid, 1956) but, with sheep, quite marked quantities were found at the anterior end of the alimentary canal, i.e. in the reticulo-rumen. The ${ }^{89} \mathrm{Sr}$ found in the rumen may have been largely secreted in the saliva, for the flow of saliva in sheep is comparatively much greater than it is in rats or in non-ruminants generally.

Because of the lack of discrimination against strontium during the excretion of the two nuclides into the alimentary canal, the sheep seems to retain more radioactivity than non-ruminant species when the material is given intravenously (Pecher, I94I; Jowsey, Owen, Tutt \& Vaughan, 1955). Retention of an oral dose does not seem to be higher, at least under the conditions of these experiments. However, it is possible that such discrimination as is shown here is not a constant process and may depend on the calcium status of the animal or the level of other dietary constituents. Thus, Palmer, Thompson \& Kornberg (1958) have shown that in certain circumstances discrimination between calcium and strontium during absorption from the alimentary canal of rats may vary with the levels of calcium and phosphorus in the diet. It is important to bear this finding in mind when comparing our results with those obtained from hill sheep during the various surveys of the ${ }^{90} \mathrm{Sr}$ content of sheep bones. 
SUMMARY

I. Carrier-free ${ }^{89} \mathrm{Sr}$ and ${ }^{45} \mathrm{Ca}$ of high specific activity were administered simultaneously to Blackface wethers, both orally and intravenously. The absorption, retention and excretion of the two nuclides were studied.

2. After simultaneous oral administration, the proportion of the dose absorbed and deposited in the skeleton was for ${ }^{45} \mathrm{Ca}$ four times that for ${ }^{89} \mathrm{Sr}$.

3. Considerable discrimination against strontium occurred during the excretion of calcium and strontium by the kidney, the ratio being about $6: \mathrm{x}$.

4. The alimentary canal was much the more important route for the excretion of $\mathrm{Ca}$ and Sr. During excretion into it there was no discrimination between calcium and strontium either in total quantity or in the rate of initial appearance in the various regions of the gut.

5. Both calcium and strontium were excreted into all parts of the alimentary canal, but principally into the small intestine.

6. There appeared to be little or no discrimination between calcium and strontium during their transfer from serum to bone.

We thank Miss R. M. Campbell for help in the preparation of many of the specimens, and Miss J. Garden for carrying out much of the counting of the radioactivity. The work was supported in part by a grant from the Agricultural Research Council.

\section{REFERENCES}

Alexander, G. V., Nusbaum, R. E. \& MacDonald, N. S. (I956). F. biol. Chem. 218, 9 I I. Bryant, F. J., Chamberlain, A. C., Morgan, A. \& Spicer, G. S. (I957). F. nucl. Energy, 6, 22. Clark, E. P. \& Collip, J. B. (1925). F. biol. Chem. 63, 46I.

Comar, C. L., Russell, R. S. \& Wasserman, R. H. (1957). Science, 126, 485.

Comar, C. L. \& Wasserman, R. H. (1956). Progr. nucl. Energy, Ser. 6. Biol. Sci. r, i53.

Comar, C. L., Wasserman, R. H. \& Nold, M. M. (1956). Proc. Soc. exp. Biol., N. Y., 92, 859.

Comar, C. L., Whitney, I. B. \& Lengemann, F. W. (I955). Proc. Soc. exp. Biol., N. Y., 88, 232.

Duckworth, J. \& Hill, R. (1958). Unpublished observations.

Harrison, G. E., Jones, H. G. \& Sutton, A. (1957). Brit. F. Pharmacol. 12, 336.

Harrison, G. E., Raymond, W. H. A. \& Tretheway, H. C. (1955). Clin. Sci. r4, 68 I.

Jones, H. G. \& Coid, C. R. (1956). Clin. Sci. 15, 541.

Jowsey, J., Owen, M., Tutt, M. \& Vaughan, J. (1955). Brit. F. exp. Path. 36, 22.

Morgan, A. \& Wilkins, J. E. (1959). Biochem. F. 7I, 4 I9.

Palmer, R. F., Thompson, R. C. \& Kornberg, H. A. (1958). Science, 127, 1505.

Pecher, C. (1941). Proc. Soc. exp. Biol., N.Y., 46, 86.

Vogel, A. I. (195 I). A Textbook of Quantitative Inorganic Analysis, and ed. London: Longmans, Green and Co.

Wasserman, R. H., Lengemann, F. W. \& Comar, C. L. (1958). F. Dairy Sci. 4I, 812. 